\title{
The contribution of alanine and leucine to the energetic processes and tissue lipid synthesis in vivo in suckling lambs
}

\author{
$S$ Vovk \\ Lviv State Agricultural Institute, 292040, Lviv-Dubliany, Ukraine
}

Previously we have established in vitro that, in the skeletal muscles of cattle of various ages, alanine and leucine were utilized not only in protein synthesis, but that their carbon metabolites also played an important role in substrate supply for lipid synthesis and tricarboxylic acid cycle (Vovk and Yanovich, 1990, Biokhimia, 55, 11, 2090-2094). Therefore, investigations on the in vivo contribution of alanine and leucine to these processes in skeletal muscles and other tissues of ruminants are of scientific and practical interest.

The objective of our study was to investigate the contribution of these amino acids to the energetic processes and tissue lipid synthesis in vivo in suckling lambs, as compared with the utilization of glucose in these processes. Three groups of suckling Precose male lambs were used, with three animals in each group. Their live weights were $5.8-6.4 \mathrm{~kg}$. Ewes were offered a diet consisting of concentrates $(0.3 \mathrm{~kg})$, beet $(2.0 \mathrm{~kg})$, meadow hay $(1.0 \mathrm{~kg})$ and barley straw ad libitum. The lambs of the first, second and third groups were given 3145 $\mathrm{kBq}$ of $\mathrm{L}-\left[\mathrm{U}-{ }^{14} \mathrm{C}\right]$ glucose, $\mathrm{L}-\left[\mathrm{U}-{ }^{14} \mathrm{C}\right]$ alanine or $\mathrm{L}-\left[\mathrm{U}-{ }^{14} \mathrm{C}\right]$ leucine per $1 \mathrm{~kg}$ of live weight, respectively. Radioactive substrates were administered in a physiological solution intraperitoneally, four hours after the morning feeding. Lambs were then placed into respiration chambers for 5 hours in order to collect the expired ${ }^{14} \mathrm{CO}_{2}$. Carbon dioxide was trapped in $20 \%$ aqueous solution $\mathrm{NaOH}$ and its radioactivity was determined in aqueous-

$\begin{array}{lc}- & \\ \text { Tissues } & {[\mathrm{U}-14 \mathrm{C}] \text { glucose }} \\ \text { Muscle } & 1.3 \pm 0.2 \\ \text { Liver } & 4.7 \pm 0.3 \\ \text { Brain } & 6.3 \pm 0.5 \\ \text { Lungs } & 3.3 \pm 0.4 \\ \text { Duodenum mucosa } & 2.9 \pm 0.6 \\ \text { Adipose tissue } & 2.2 \pm 0.2\end{array}$

compatible scintillation fluid. Animals were then killed, and samples of quadriceps fenoris muscle, liver, brain, lungs, duodenum mucosa and subcutaneous adipose tissue were excised. Samples were immediately frozen in liquid nitrogen, freeze-dried and pulverized. Pulverized tissues were extracted with chloroform/methanol (2:1) according to Folch et al (1957, J Biol Chem, 226, 497-509). Extracts were evaporated at $60^{\circ} \mathrm{C}$ under vacuum and lipids were dissolved in a commercial scintillation fluid. The radioactivity of samples was measured in a LKB liquidscintillation counter.

It was established that the radioactivity of ${ }_{14} \mathrm{CO}_{2}$ formed during the oxidation of carbon chains of $\left[\mathrm{U}-{ }^{14} \mathrm{C}\right]$ glucose, $\left[\mathrm{U}-{ }^{14} \mathrm{C}\right]$ alanine and $\left[\mathrm{U}-{ }^{14} \mathrm{C}\right]$ leucine in the body of lambs during the investigated period was $36.0 \pm 6.0,28.4 \pm 2.8$, and $8.4 \pm 0.4 \times 10^{6} \mathrm{dpm}$ per $1 \mathrm{~kg}$ of body weight, or $100.0,78.8$, and $23.3 \%$, respectively. The results of the incorporation of radioactivity of carbon derivates of glucose, alanine and leucine into the total lipids of the tissues of lambs are summarized in the table. The radioactivity of lipids in the table is expressed in $10^{3} \mathrm{dpm}$ per $1 \mathrm{~g}$ dry matter, means $\pm S D, n=3$.

On the whole, the results obtained supply evidence for a significant role and specificities in the in vivo utilization of carbon metabolites of alanine and leucine in energetic processes of body and lipid synthesis in the mentioned tissues of suckling lambs.

$[\mathrm{U}-14 \mathrm{C}]$ alanine
$5.9 \pm 0.6$
$13.8 \pm 1.2$
$16.7 \pm 1.7$
$7.3 \pm 0.5$
$10.6 \pm 0.9$
$6.1 \pm 1.1$

